\title{
Analysis of Dry Maize Grain Market Integration in Kipkelion East and West Sub Counties, Kericho County, Kenya
}

\author{
Sang Isaac Kipchirchir ${ }^{1, ~ *, ~ N g ' e n o ~ E l i j a h ~ K i p l a n g a t ~}{ }^{2}$, Kibett Joash Keino ${ }^{3}$ \\ ${ }^{1}$ Department of Agricultural Bio Systems and Economics, University of Kabianga, Kericho, Kenya \\ ${ }^{2}$ Department of Applied Economics, School of Economics, University of Eldoret, Eldoret, Kenya \\ ${ }^{3}$ Department of Horticulture, University of Kabianga, Kericho, Kenya
}

Email address:

kipchirchirisaac81@gmail.com (S. I. Kipchirchir), engeno489@gmail.com (N. E. Kiplangat), jkibett@kabianga.ac.ke (K. J. Keino)

${ }^{*}$ Corresponding author

\section{To cite this article:}

Sang Isaac Kipchirchir, Ng'eno Elijah Kiplangat, Kibett Joash Keino. Analysis of Dry Maize Grain Market Integration in Kipkelion East and West Sub Counties, Kericho County, Kenya. Journal of World Economic Research. Vol. 9, No. 2, 2020, pp. 73-80.

doi: $10.11648 /$ j.jwer.20200902.11

Received: August 29, 2019; Accepted: September 22, 2019; Published: June 17, 2020

\begin{abstract}
This study analyzed market integration of dry maize grain in Kipkelion East and Kipkelion West Sub-Counties in Kericho County, Kenya. The objective of the study was to determine the correlation of prices between the terminal and source markets of dry maize grain. Purposive and stratified random sampling procedures were used to collect data from a sample of 156 maize traders. The survey data analysed using regression and Pearson's product-moment correlation models. Results shows that $53.8 \%$ of the dry maize grain traders were males and $46.2 \%$ were females with $46.2 \%$ dry maize grain traders having attained secondary school level of education. Regression and correlation results shows that a unit increase in the dry maize grain source market prices would result in a $98.2 \%$ increase in the terminal maize market prices. Pearson's Product-Moment correlation results showed that there was positive relationship between the terminal and the source market prices with $68 \%$ of variation in terminal market prices being explained by all the source market prices. High prices in the source markets would lead to higher prices as well in the terminal markets. In order to achieve market integration, improve market information flow and promote competitiveness between the source and terminal markets in the county and in the country, this study recommends the enactment of relevant policies by the government agencies, both in the county and in the national government. There is also need to improve market information flow in the county; particularly the use of information and communication technology in order to ensure timely and faster flow of information across the dry maize grains markets. If traders, producers and consumers are given timely market information, it will reduce cases of price shocks and promote market integration.
\end{abstract}

Keywords: Dry Maize Grain, Market Integration, Source Market, Terminal Market, Pearson's Product-Moment Correlation

\section{Introduction}

Maize (Zea mays) is one of the significant cereal crops for both human and animal consumption [1]. Maize is the third preferred traded cereal worldwide after wheat and rice; its production is estimated to be 828 million tonnes [2]. In Africa and Latin America maize is a staple food due to its low prices and worldwide distribution. Currently, the majority of livestock farmers use maize as feed for animals. Maize is also very accommodative in terms of ecological requirements. It does well in various soils, altitude, and fertility conditions; this is why it is well adapted to most parts worldwide and the reason of having many varieties in the market for production [3].

In the world market, maize still attracts a few exporting countries, but there are numerous importers across the world. The United States is the key player in the maize market, since it is the world's major producer, consumer, and exporter. However, countries like Brazil, China, and Argentina have emerged to be active in the international market. Globally maize sector has been dominated by a large number of private firms who control operations such as storage, transportation in the supply chain, with an elongated worldwide appearance [4]. World maize prices rose 
seasonally in the first months of 2019, after a significant drop in 2018 with the commercialization of the main and second season harvests [5]. Maize demands in the developing world will be double between now and 2050. By 2025, it will have become the crop with the greatest production globally and in the developing world [6]. However, agricultural marketing has been side-lined for several years. Production is given a lot of emphasis since the majority of the population believe that production is more significant than marketing. Economists and planners have re-assed this belief with an objective of making sure agricultural marketing is accorded more attention in terms of economic development [7].

Marketing system in less developed and developing countries is still lagging behind in terms of efficiency. In order to promote agricultural production and economic growth, a lot of emphasis and enormous recognition of efficient marketing system needs to be considered [7]. In Kenya the maize sector is an important sector. Therefore, maize marketing is an important area, hence requiring the parties involved to be in a position of understanding price setting mechanisms. Maize value chain in Kenya is comprised of market players, input suppliers, processors, post processors and farmers. Competition exists between these different players [8]. Dry maize grains are sold to National Cereals and Produce Board (NCPB) and directly to individual traders/consumers. Marketing of dry maize grain is faced with challenges such as competition in the market, climate hazards, diseases, poor infrastructures and poor marketing strategies [9].

Market integration is regarded as a major market research tool that gives clear picture of how a given market functions. Understanding market integration enhances policy making and decision making in resource allocation in production. Market integration also provides sufficient knowledge on the behaviour of supply and demand in a market for a given product. In maize production and marketing, just like for any other enterprise, utilizes resources across space and time in order to yield better returns. Therefore, through market integration efficiencies in resource allocation can be achieved; thus better returns realization [10].

The important aspect of market research is market integration since it provides the basic information for comprehending how particular markets work. The significance of the information obtained depends in its application to drafting of policies and decisions, on the extent of promoting market development. In addition, the understanding of movement equilibrium paths of market forces (supply and demand) for a specific commodity or group of produce highly depends on market integration. The level of proximity of the accuracy and speed of diffusion of market price information or spread of information/ price transmission efficiency and price movement are prerequisites for attaining efficient spatial and temporal resource allocation [11]. If markets are efficient and interlinked, price comovement in such markets can be achieved. However, no research has been done on dry maize grain markets in Kericho County. In addition, the factors causing variations in the market prices of dry maize grains are not fully understood.

Marketing of dry maize grain in Kericho County is one of the ventures that contribute to income generation to majority of the population. Dry maize grains are sold to consumers within the county and bordering counties like Kisumu, Kisii, Nandi, Uasin Gishu, Bomet and Nakuru. Traders also sell their dry maize grains to Kericho, Fort Ternan, Kipkelion and Kedowa National Cereal Produce Board (NCPB) depots [12]. In Kipkelion East and West Sub-Counties, dry maize grains production is of great significance and it contribute $68 \%$ of the total county production [13]. This implies that maize marketing in these sub-counties play a vital role in income generation to a larger population. However, if markets are efficient and interlinked, trade will be beneficial to both producers and consumers.

Integrated markets in literature are those markets with negligible differences in price of a given commodity and which allows effectiveness of commodity transfer and intermarket transmission of price shock; thus such markets can trade efficiently [14]. However, this is not the case being observed in the terminal and source markets for the study areas of Kipkelion East and Kipkelion West Sub-Counties in Kericho County. Previous studies carried out in Nairobi, Nakuru, Eldoret and Kitale focused on market integration of dry beans [14]. However, studies on dry maize grain market integration have not been undertaken, especially for the terminal and the source markets in the current study area. The major markets for the dry maize grain in Kericho County are Chepseon, Londiani in Kipkelion East Sub-County and Fort Ternan, Kamasian and Barsiele in Kipkelion West SubCounty.

There is evidence attached to the significance of market integration. Knowledge gap still exists in literature on the extent of dry maize grain inter-markets integration in Kenya. Hence, price information does not reach farmers, traders, and consumers. Therefore, the findings of this study will benefit traders, producers, consumers, processors and policy makers nationally. It will enable traders, producers, consumers and processors organize their resources efficiently and increase specialization. It will also increase their economies of scale in production, minimized costs incurred in marketing, increase access to new varieties of products and obtain dry maize grain in market at lower prices. It will also enable traders and processors to ascertain whether the business they are engaged in will be yielding profit or loss. Policy makers in Kenya will be in a position to draw policy guidelines which will assist the government to regulate the dry maize grains markets.

\section{Methodology}

\subsection{Research Design}

This study was done in Kipkelion East and West SubCounties of Kericho County, Kenya using descriptive research design. A total of 156 maize traders were sampled 
and used in the study.

\subsection{Sampling Procedure and Sample Size}

The study employed purposive and stratified random sampling procedures to get the total sample size of interest for five dry maize grain markets in the two sub counties. The sub counties were stratified into the five dry maize grain markets. Sample selection of maize traders from the market strata was then done using random sampling. Effort was also made to include statistically significant sub samples of dry maize grain producers in each of the sub counties. A total of 156 respondents were sampled and proportionately distributed across the five markets as shown in table 1 .

The dry maize grain $n^{\text {th }}$ trader was determined by the proportionate size sampling methodology as shown in equation (1).

$$
n=\frac{N C^{2}}{C^{2}+(N-1) e^{2}}
$$

Where $\mathrm{n}$ is the sample size, $\mathrm{N}$ is the population size $(35,500), \mathrm{C}$ is the coefficient of variation (which is $25 \%$ ), and $e$ is the margin of error (2\%) [15]. The sample units were calculated based on equation (1) for the number of dry maize grain traders in each maize market in the two sub counties against the desired sample size of 156 as shown in table 1 . Based on the above mentioned criteria, the random sample of dry maize grain traders selling and buying dry maize grains in the two sub counties consisted of 44 traders in Chepseon, 28 in Londiani, 41 in Fort Ternan, 23 in Kamasian and 20 in Barsiele dry maize grain markets respectively. Therefore, based on the above calculations, the sample size of traders was 156 which were then used for data analysis in this study.

Table 1. Proportionate Sample Size of Dry Maize Grain Traders per Market.

\begin{tabular}{lllll}
\hline S. No. & Market & $\begin{array}{l}\text { Target } \\
\text { population (N) }\end{array}$ & Percentage & $\begin{array}{l}\text { Sample } \\
\text { Size (N) }\end{array}$ \\
\hline 1. & Chepseon & 9,900 & 28 & 44 \\
2. & Londiani & 6,390 & 18 & 28 \\
3. & Fort Ternan & 9,400 & 26 & 41 \\
4. & Kamasian & 5,210 & 15 & 23 \\
5. & Barsiele & 4,600 & 13 & 20 \\
& Total & 35,500 & 100 & 156 \\
\hline
\end{tabular}

\subsection{Data Types}

Given the objective of identifying the determinants of market integration of dry maize grain in Kipkelion East and Kipkelion West Sub-Counties in Kericho County, Kenya, the population of interest was defined as the primary dry maize grain traders who sold dry maize grains in any of the five source and terminal maize markets. For that reason, traders who did not sell any dry maize grains or sold processed maize grains were not included in the study. Therefore, given this restriction, its uniqueness, the sample for this study could not be directly compared with the county or national official data on the general structure of dry maize grain production.

Data types used encompassed representative sample of dry maize grain representing the five maize markets. Data collected included maize traders' socio-economic characteristics, actual dry maize grains traded, dry maize grain selling and buying prices, mode of transport, transportation costs, marketing information and other incurred costs during the marketing process, average retail price data per month for a four-year period from January 2014-December 2017 from the terminal and source markets, main market players and price transmission. Respondents were also expected to provide information regarding market competitiveness and estimated total number of dry maize grain traded in 90 kilogram bags.

\subsection{Data Collection Instruments}

Primary data and secondary was used in this study. Primary data was collected directly from the respondents in the markets by use of interview schedules while secondary data was obtained from Ministry of Agriculture, books and other documents that were relevant to the research study. Secondary data was collected by use of a document analysis form and the respondents were the Sub County and County crops and agri-business officers.

\subsection{Analytical Frameworks}

\subsubsection{Theoretical Models}

Spatial and temporal transmission of price coupled with its speed will determine the ability of the marketing system to perform its function efficiently hence promoting market efficiency. The study laid its emphasis on spatial market integration that calls on study of price relationships of dry maize grain in spatially differentiated markets. Market integration promotes competition and trade between markets and the producers will increase their production hence attaining better income and improved living standards [16]. Markets will work efficiently if they are fully integrated. However, in reality, an efficient market may fail to operate due to the presence of some factors that prevent its efficiency. For example; high transaction costs impedes the flow of price information of various products in the markets. These transaction costs are categorized as fixed and variable. Fixed transaction costs include costs involved in constructing road network and installing communication facilities, while variable transaction costs comprise of transportation costs. Variable transaction costs depends on the quantity of products being handled, the higher the quantity the lower the costs incurred in trading process and vice versa [17]. Therefore, this study was able to build its analysis on price difference theory which states that; 'the price difference in any two markets trading together equals the transfer costs.' This can be explained as price of a given product e.g. dry maize grain in time $t$ is $\mathrm{P}_{1 t}$ and $\mathrm{P}_{2, t}$ in market 1 and 2 respectively. The two markets will be integrated only if the variation between the prices is the transaction costs as shown in equation 2 [18].

$$
\mathrm{P}_{1}=\mathrm{P}_{2}+\mathrm{K}
$$


Therefore, market 1 and 2 can trade only if $\left|\mathrm{P}_{1}-\mathrm{P}_{2}>\mathrm{K}\right|$ ratifying the theory that ensures the prices of similar products being traded in any two separated markets are equal. However, if this is true, then the Law of One Price (LOP) can apply whose theory postulates that, given prices of a product in two spatially separated markets as $\mathrm{P}_{\mathrm{i}, \mathrm{t}}$ and $\mathrm{P}_{\mathrm{j}, \mathrm{t}}$ at all points in time, the price difference should be the transfer costs for transporting the product from market $i$ to market $j$ [18]. If the prices in the two markets are found to be having no relationship, then both market integration and price transmission will be lacking, resulting in market segmentation [19]. This is illustrated in equation 3 .

$$
\mathrm{P}_{i t}=\mathrm{P}_{j t}+\mathrm{C}
$$

Where, $\mathrm{C}$ is the marginal transfer cost from market $i$ to market $j$. Therefore, if this theory is depicted in market $\mathrm{i}$ and $\mathrm{j}$ the two markets are integrated. However, in extreme cases where market integration and price transmission between two markets are lacking due to segmentation, it results in a strong form LOP. This in reality rarely occurs since prices of a product will always vary by an amount at most equal to transfer cost. This can be illustrated in equation 4 .

$$
\mathrm{P}_{i t}-\mathrm{P}_{j t} \leq \mathrm{C}
$$

The above represent an equilibrium condition, which indicates that the prices being witnessed in markets may differ from what is being observed in equation 2 but spatially arbitrage will always cause variation between the two prices to move towards the transfer cost.

\subsubsection{Econometric Analysis}

The econometric analysis consisted of correlation and regression analysis and Pearson's Product-Moment correlation models. Correlation and regression analysis was used to test the relationship between prices in terminal and the source markets. When a long-run linear relation exists among different price series, these series are said to be cointegrated. If terminal and source markets are integrated, then there is an existence of an equilibrium relationship amongst them [20, 21]. Long run equilibrium relationship for analyzing market integration can be illustrated in equation 5 .

$$
\mathrm{Y}_{t}=\alpha+\beta \mathrm{X}_{t}
$$

Where $\mathrm{Y}_{t}$ and $\mathrm{X}_{t}=$ are equal prices of a commodity in two spatially separated markets; source and terminal respectively. $\alpha$ and $\beta$ are parameters to be estimated. If $\alpha=0$, then the two market prices are equal. This was based on the Law of One Price (LOP) [20]. However, the objective of this study was analyzed using typical regression model to test for market integration between two spatially separated markets as indicated in equation 6 below.

$$
\mathrm{Y}=\alpha+\beta \mathrm{X}_{t}+\mathrm{u}_{t}
$$

Where $\mathrm{X}_{t}$ is the price series for central (source) market in $\mathrm{t}$ time, $\mathrm{Y}_{\mathrm{t}}$ is the price series for peripheral (terminal) market in t time, $\alpha$ is the the intercept term, $\beta$ is a parameter of the slope, and $u_{t}$ is the error term. If source and terminal markets are perfectly spatially integrated, then $\beta=1$. If this holds, then price changes in terminal markets will be fully reflected in the source markets and vice versa. When $\beta \neq 1$ (i.e. $\beta<1$ or $\beta>1$ ), then the extent of integration may be evaluated by investigating how far the deviation of $\alpha_{1}$ is from unity.

The aim of carrying out regression analysis was to be more reflective of the population than the mean (dependent value, or Y) alone, which would otherwise be the best estimate of the predicted value from a set of the given values. The study was concerned with whether the relationship pattern between two values of variables could be described as a straight line, which was the simplest and most commonly used form. The relationship between the source and the terminal market prices of dry maize grain was tested in the study. From policy researcher perspective regression coefficient, $\beta$ is typically more important than the intercept, since the policy makers are usually interested with the effect of one variable on another. The greater the regression coefficient, the more influence the independent variable has on the dependent variable, and the more change in $\mathrm{Y}$ associated with a change in $\mathrm{X}$.

Pearson's product-moment correlation, $r$, was used to measures the tightness of fit of $\mathrm{X}, \mathrm{Y}$ coordinates around the regression line of a scatter plot. Computed values of Pearson's $r$ can range from -1 to +1 [22]. The larger the absolute value of $r$, the tighter the fit of $\mathrm{X}, \mathrm{Y}$-coordinates around the regression line. When the regression line slopes upward, we have a positive correlation. Pearson's $r$ will be positive up to a value of +1 , whereas when the regression line slopes downward, we have a negative correlation. Pearson's $r$ will be negative down to a value of -1 and finally, when the regression line is flat, we have no correlation and Pearson's $r$ $=0$.

\section{Results and Discussion}

\subsection{Socio-economic Characteristics of Dry Maize Grain Traders}

Table 2 shows the gender distribution of the dry maize grain traders. The analyzed results shows that $53.8 \%$ of the dry maize grain traders were males and $46.2 \%$ were females. This indicated that dry maize grain trade was dominated by male traders.

Table 2. Gender Distribution of of Dry Maize Grain Traders.

\begin{tabular}{lll}
\hline Gender & Frequency & Percent (\%) \\
\hline Male & 84 & 53.8 \\
Female & 72 & 46.2 \\
Total & 156 & 100.0 \\
\hline
\end{tabular}

Results in table 3 show the age distribution of the respondents. As shown, $76.9 \%$ of the dry maize grain traders were aged more than 36 years. The surveyed dry maize grain traders were aged between 30-35, 24-29 and 18-23 years 
were $13.5 \%, 8.3 \%$ and $1.3 \%$, respectively.

Table 3. Respondent's Age Distribution.

\begin{tabular}{lll}
\hline Age Range & Frequency & Percent $\mathbf{( \% )}$ \\
\hline 18-23 years & 2 & 1.3 \\
24-29 years & 13 & 8.3 \\
30-35 years & 21 & 13.5 \\
Over 36 years & 120 & 76.9 \\
Total & 156 & 100.0 \\
\hline
\end{tabular}

Table 4 presents results on the levels of education attained by the surveyed dry maize grain traders. Results revealed that $46.2 \%$ of the dry maize grain traders had attained secondary school level of education, whereas $44.9 \%, 6.4 \%$ and $2.6 \%$ of traders had attained primary, college and University levels of education respectively. These results show that most of the dry maize grain traders in the study area have primary and secondary levels of education. Education was found to be playing an important role in the adoption of innovation. Education in itself was considered vital in trading business. Household heads with at least a secondary level of education increased household understanding of market dynamics and hence improved decisions about the quantity of output sold [23].

Table 4. Education Levels of Respondents.

\begin{tabular}{lll}
\hline \multicolumn{1}{c}{ Education Level } & Frequency & Percentage (\%) \\
\hline Primary & 70 & 44.9 \\
Secondary & 72 & 46.2 \\
College & 10 & 6.4 \\
University & 4 & 2.6 \\
Total & 156 & 100.0 \\
\hline
\end{tabular}

\subsection{Determinants of Dry Maize Grain Market Integration Between Terminal and Source Markets}

Table 5 of results shows the sources of dry maize grains for the maize traders. The study results shows that $91.7 \%$ of the dry maize grain traders sourced their dry maize grain from maize farmers. $6.4 \%, 6 \%$ and $1.3 \%$ of surveyed traders sourced their dry maize grain from dry maize grain agents, wholesalers and other sources respectively. Farmers were found to be the main maize producers and hence the major source of bought dry maize grains by the maize traders in both the source and the terminal markets in the study area.

Table 5. Source of Dry Maize-Grain.

\begin{tabular}{lll}
\hline Source & Frequency & Percent (\%) \\
\hline Farmer & 143 & 91.7 \\
Agent & 10 & 6.4 \\
Wholesalers & 1 & .6 \\
Other & 2 & 1.3 \\
Total & 156 & 100.0 \\
\hline
\end{tabular}

Table 6 present results on factors that are considered by the maize traders while purchasing dry maize grains in the terminal and the source markets. $64.7 \%$ of the sampled respondents reported price as the most influencing factor that was considered by maize traders when making decision on where to purchase dry maize grains. However, $27.6 \%$, and $7.1 \%$ of the respondents considered distance and means of transport to be the main two factors that were considered by maize traders while purchasing dry maize grains. Spatial price linkages within maize markets allow efficient movement of products across markets due to efficiency of price information flow [24]. The study further found out that there was critical need to provide more price information to dry maize grain traders to enable them benefit from spatial price difference. This earlier study was found to be convergent with the current study, since in both studies, price was established to be the main determining factor. It was evident from the results that distance contributes to poor maize marketing by the dry maize grain traders across the markets in the study area. Dry maize grain traders consider travelling and transport distance while buying dry maize grain since distance is a function of price and thus, the further the distance from the source to terminal market, the greater the transaction cost, and eventually impacting on the final selling price. A major constraint to the intensity of market participation among traders was distance from the farm to point of sale [25]. Further, result findings shows distance to market has a negative impact on both proportion of marketable load size and the decision to participate in the market [23-26]. These previous findings are in convergence with the findings of the current study. Price and formal market information sources greatly intensify market participation [25]. The current study results are in lined with the findings of the case study of Punjab and Pakistan which showed that, lack of market information, long distances from farm to market and high transportation cost threatened accessibility to terminal market for agricultural produces by small scale producers [27].

Table 6. Factors Considered when Buying Dry Maize Grains by Maize Traders.

\begin{tabular}{lll}
\hline Factors & Frequency & Percent $\mathbf{( \% )}$ \\
\hline Distance & 43 & 27.6 \\
Price & 101 & 64.7 \\
Means of transport & 11 & 7.1 \\
Other & 1 & 0.6 \\
Total & 156 & 100.0 \\
\hline
\end{tabular}

Table 7 presents results of the different types of transaction costs in the source and terminal markets incurred by the dry maize grains traders. From the results, traders incurred on average Kenya Shillings (Ksh.) 72.17 per 90 kilogram $(\mathrm{Kg})$ of dry maize grain as transport cost. This is followed by the cost per trip and offloading costs at an average of Ksh. 64.39 and Ksh. 16.38 per $90 \mathrm{~kg}$ of dry maize grain respectively. Cess charges had the lowest average cost of Ksh.10.11 per $90 \mathrm{~kg}$ of dry maize. The major component of marketing cost as per the previous study was packaging $(82.63 \%)$ and transportation charges $(10.74 \%)$ [28]. However, the author's findings on packaging charges and transport charges were in 
divergence with the current study findings.

Table 7. Dry Maize Grain Transaction Costs.

\begin{tabular}{llll}
\hline Type of cost & N & Mean & Std. Deviation \\
\hline Cost per trip (90kg) & 156 & 64.39 & 47.798 \\
Labour for loading 90kg bag & 156 & 18.46 & 12.123 \\
Storage cost & 156 & 34.20 & 58.559 \\
Offloading cost & 156 & 16.38 & 10.342 \\
Transport cost & 156 & 72.17 & 51.945 \\
Market Charges (handling \& brokerage charges) & 156 & 28.40 & 35.786 \\
Packaging cost & 156 & 30.56 & 15.839 \\
Cess Charges & 156 & 27.05 & 10.110 \\
Valid N (list wise) & 156 & & \\
\hline
\end{tabular}

Table 8 of results on access to market information by dry maize grain traders on the study area revealed that $93.6 \%$ of the dry maize grain traders accessed market information as compared to $6.4 \%$ of the traders who did not. This therefore, implied that issues of oversupply and undersupply of dry maize grain in terminal and source markets need not to arise. Access to market information is critical to both producers and traders in settling on a price and locating a seller or a buyer of dry maize grain. This would increase their shares in the value chain and their bargaining power, thus lowering market manipulation by the few traders and promote market integration and efficiency [29]. The study on whether maize farmers are able to access market information, found out that both rural and peri-urban market farmers had access to market information on prices and quantities of commodities [25]. Access to market information reduces transaction costs and improves bargaining power among small-scale farmers [30]. All these earlier study findings are in convergence with the current study findings. The current study results on access to market information are also in agreement with the findings on determinants of rural and co-operative market choice among small holder yam farmers in the Brong Ahafo region of Ghana [31]. The study results show that access to market information play a key role in determining the choice of market among smallholder yam farmers [31].

Table 8. Access to Market Information.

\begin{tabular}{lll}
\hline & Frequency & Percent $\mathbf{( \% )}$ \\
\hline Yes & 146 & 93.6 \\
No & 10 & 6.4 \\
Total & 156 & 100.0 \\
\hline
\end{tabular}

Table 9 of results shows the various sources of market information for the dry grain maize traders in the study area. Results revealed that $76.9 \%$ of the dry maize grain traders received market information on dry maize grains markets by physically visiting the maize market places, whereas $15.4 \%$ of the traders received dry maize grain information through electronic media. The remaining $6 \%, 5 \%$ and $1 \%$ of the traders received dry maize market information from government officials, NCPB and from agricultural extension officers, respectively. Previous study results shows that most of the households who were involved in rural and peri-urban maize marketing obtained market information through formal and informal sources such as radio, television, newspapers, friends, public or private organizations, social networks of neighbours and relatives [25].

Table 9. Source of Dry Maize Grain Market Information.

\begin{tabular}{lll}
\hline & Frequency & Percent (\%) \\
\hline By visiting market place & 120 & 76.9 \\
From NCPB & 8 & 5.1 \\
From government officials & 1 & 0.6 \\
From electronic media & 24 & 15.4 \\
From Agricultural extension officers & 2 & 1.3 \\
Others & 1 & 0.6 \\
Total & 156 & 100.0 \\
\hline
\end{tabular}

\subsection{Correlation of Dry Maize Grain Prices Between Terminal and Source Markets}

Table 10 shows the results of the regression and correlation between the terminal and the source markets for the dry maize grains. Regression and correlation analysis was used with the sole purpose of determining the relationship between the terminal and source markets prices for the study area. The results show that R-squared value of 0.466 means that approximately $46.6 \%$ of the variance of terminal market price was accounted for by the model. In this case, the predictor variable was the source market price. The regression coefficients represent the mean change in the terminal market price for one unit change in the source market price while holding other predictors in the model constant.

Table 10. Correlation between Terminal and Source Markets for Dry Maize Grain.

\begin{tabular}{lllllll}
\hline Terminal Market & Coefficient & Std. Err. & t & P>t & Interval] & [95\% Conf. \\
\hline Source Market & 0.9820277 & 0.0847116 & 11.59 & 0.000 & 0.814681 \\
Constant & 395.5004 & 141.3782 & 2.80 & 0.006 & 1.149374 \\
\hline
\end{tabular}

Legend: Number of observations $=156, \mathrm{~F}(1,154)=134.39$, R-squared=0.4660, Adj R-squared $=0.46$, Root MSE $=284.4$ 
The statistical control that the regression provides for this study was important because it isolated the role of one variable from all the others in the model. The $t$-test for source market price equals 11.59 , which was statistically significant at $95 \%$ confidence interval. This means that the regression coefficient for source market is significantly different from zero. The coefficient of source market was 0.982 , which means that for every unit increase in source market price would result in a $98.2 \%$ increase in terminal market price. The constant value was 395.5, and this was the predicted value when the source market value was zero.

Table 11 of results shows the linear relationship between the source and the terminal dry maize grain markets. The results were tested by performing the Pearson's ProductMoment correlation. The test was used to assess the strength of the linear of the relationship between the terminal and the source market prices of dry maize grains among the surveyed 156 maize traders in Kipkelion East and West Sub-Counties in Kericho County. The Pearson's Product-Moment correlation results shows that the correlation coefficient, $r$, was 0.83 with a significant $p$-value less than 0.05 . The result shows that there was a strong positive relationship between the terminal and the source market prices of dry maize grains. The coefficient of determination $\left(\mathrm{r}^{2}\right)$ for the source market of 0.68 explains $68 \%$ of variation in terminal market price which is explained by all the source market prices. This result means that high prices in the source markets would lead to higher prices as well in the terminal markets. The finding will thus promote dry maize grain trading since traders will be willing to participate in the business because the trade would results in better income generation.

Table 11. Pearson's Correlation between Source and Terminal Dry Maize Grain Markets.

\begin{tabular}{lll}
\hline & Terminal Market & Source Market \\
\hline Terminal Market & 1.0000 & 0 \\
Source Market & $0.6826^{*} 0.0000$ & 1.0000 \\
\hline
\end{tabular}

$r^{2}=0.6826 r=0.83$

According to the study finding on the use of mobile phones in Niger over the years between 2001 and 2006, and its impact on grain markets, results indicates that the usage of mobile phones minimized grain price difference between markets by at least $6.4 \%$ and minimized inter-seasonal price variations by $10 \%$ [32]. The effect of usage of mobile phones was even higher in areas with poor quality of roads, which was in convergence with the current study findings. However, a study on the Nigerian maize market price to world maize market prices found a weak response but a strong co-movement of domestic maize prices and those of neighbouring West African countries [33]. The study findings on price transmission across Global markets and SubSaharan Africa (SSA) domestic maize markets showed that most local price series correlate to regional neighbours maize markets [34]. These findings were also convergent with the current study findings.

\section{Conclusions and Recommendations}

This study analysed the regression and correlation between the terminal market prices and source market prices of dry maize grain in Kipkelion East and West Sub-Counties, Kericho County, Kenya. The correlation and regression analysis results showed statistically significant correlation between the terminal and source market prices. Regression and correlation results of the study shows that for every unit increase in the dry maize grain source market prices would result in a $98.2 \%$ increase in the terminal maize market prices. The Pearson's Product-Moment correlation coefficient results showed that there was a strong positive relationship between the terminal and the source market prices of dry maize grains. The coefficient explained $68 \%$ of variation in terminal market price which was also explained by all the source market prices. High prices in the source markets would lead to higher prices as well in the terminal markets. The finding would thus promote dry maize grain trading since traders would be willing to participate in the business because the trade would result in better income generation. Therefore, in order to promote competitiveness between the source and the terminal dry maize grain markets in the county and in the country, and to improve dry maize grain market environment, this study recommends the formulation of relevant maize production and marketing policies by the relevant government agencies, both in the county and in the national government that will help promote competition. There is also need to improve market information flow in the county; particularly the use of information and communication technology (ICT) in order to ensure timely and faster flow of information across the product markets. If traders, producers and consumers are given timely market information, it will reduce cases of price shocks and promote market integration.

\section{Acknowledgements}

The paper is an extract based on the author's MSc. work at the Department of Agricultural Bio systems and Economics, University of Kabianga, Kenya. I would like to thank my university supervisors, anonymous reviewers and the editor for their helpful comments and suggestions on this article.

\section{Conflict of Interests}

The authors declare that they have no competing interests.

\section{References}

[1] FAO (Food and Agriculture Organization), (2000). Statistical database-FAOSTAT. FAO, Rome. www.faostat.org.

[2] Government of Kenya. (2011). Economic Review on Agriculture. Annual Report Kenya. Ministry of Agriculture. Government Printers, Nairobi. 
[3] Ministry of Agriculture (2008). Economic Review on Agriculture. Annual Report Kenya. Government Printers, Nairobi.

[4] Ministry of Agriculture (2012). Economic Review on Agriculture. Annual Report Kenya. Government Printers, Nairobi.

[5] FAO. (2019). Food Prices Index and AMIS Market Monitor Report.

[6] Rosegrant, M. W., Msangi, S., Ringler, C., Sulser, T. B., Zhu T. and Cline S. A. (2008). International Model for Policy Analysis of Agricultural Commodities and Trade (IMPACT): Model Description. International Food Policy Research Institute: Washington, D. C.

[7] Mafimesebi, T. E. (2002). Spatial Price Equilibrium and Fish market Integration in Nigeria. Unpublished Ph.D Thesis. University of Ibadan, Nigeria.

[8] Raphael, G. and Ferdi. (2018). Spatial Market Integration in the Era of High Food Prices. A Case of Surplus and Deficit Maize Markets in Kenya.

[9] Ministry of Agriculture. (2014). Annual Agribusiness Reports, Kipkelion East \& West Sub-Counties, Kericho County, Kenya.

[10] Venny, K. (2013). An Assessment of Dry Beans Market Integration in SelectedMarkets in Kenya. Unpublished Msc. Thesis. Egerton University, Kenya.

[11] Jayara, D. (1992). "Spatial Pricing Efficiency in Groundnut Markets Tami Nadu". Indian Journal of Agricultural Economics, 47 (1): 79-89.

[12] Ministry of Agriculture. (2016). Annual Agribusiness Reports, Kipkelion East \& West Sub-Counties, Kericho County, Kenya.

[13] Ministry of Agriculture. (2017). Crops Annual Report, Kericho County, Kenya.

[14] Kibiego, M., Odhiambo, M. \& Kosura, W. (2006). Analysis of the Structure and Performance of the Beans Marketing System in Nairobi. International Association of Agricultural Economists Conference, Gold Coast, Australia, August 12-18, 2006.

[15] Naissuma, D. K. (2000). Survey Sampling: Theory and Methods. Nairobi: University of Nairobi Press.

[16] Ackello-Ogutu, C. \& Echessah. P. (1997). "Unrecorded crossborder trade between Kenya and Uganda: Implications for food security". Inc, 1997. Available at; http://www.scirp.org. Accessed on 10th January 2012.

[17] Williamson, O. E. (1985). The Economic Institutions of Capitalism: Firms, Markets, Contracting New York.

[18] Rapsomanikis, G., Adenegan, Kemisola O. and Anifat O. Bolarinwa. (2006). Price Transmission and Market Integration of Fish in Oyo State: Journal of Rural Economics and Development 19, (1), 1-15.

[19] Ravallion, M. (1986). “Testing Market Integration.” American Journal of Agricultural Economics, 68, (2), 102-109.

[20] Goodwin B. K, Schroeder T. C. (1991). Co-integration tests and spatial price linkages in regional cattle markets. Am. $J$. Agric. Econ., 73; 452-464.
[21] Sexton, R., C. Kling and H. Carmar. (1991)."Market Integration, Efficiency of Arbitrage and Imperfect Competition: Methodology and an Application to U.S. Celery", American Journal of Agricultural Economics, 568580.

[22] Ratner, B. J Target Meas Anal Mark (2009) 17: 139. https://doi.org/10.1057/jt.2009.5.

[23] Makhura, M, Kirsten, J \& Delgado, C, 2001. Transaction costs and smallholder participation in the maize market in the Northern Province of South Africa. Seventh Eastern and Southern Africa Regional Maize Conference, 11-15 February, Pretoria, South Africa.

[24] Ikudayisi, Adesola Adebola and Salman, Kabir. (2014). Spatial Integration Maize Market in Nigeria-A Vector Error Correction Model, International Journal of Food and Agricultural Economics (IJFAEC), Alanya Alaaddin Keykubat University, Department of Economics and Finance.

[25] John, M., David, J. Otieno, Timothy, Nyanamba, and Ellen Cullough. (2009). Factors Influencing the Intensity of Market Participation by Smallholder Farmers: A case Study of Rural and Peri-urban areas of Kenya. Afjare Vol. No. 1 March 2009.

[26] Key, N, Sadoulet, E \& de Janvry, A, 2000. Transaction costs and agricultural household supply response. American Journal of Agricultural Economics 82 (1), 245-59.

[27] Ahmed, U. I., Ying, L., Bashir, M. K., Abid, M., Elahi, E. \& Iqbal, M. A. (2016). Access to Output Market by Small Farmers: The Case of Punjab, Pakistan. The Journal of Animal and Plant Sciences, 26 (3): 2016. ISSN 1018-7081.

[28] Navadkar, D. S., Amale, A. J., Gulave, C. M \& Nannaware, V. M. (2012). Economics of Production and Marketing of Kharif Maize in Ahmednagar District of Maharashtra State.

[29] Shahidur, R., Nicholas, M., Solomon, L. and Befakadu, B. (2010). Are Staple Food Markets in Africa Efficient? Spatial Price Analyses and Beyond." Food Price Variability: Causes, Consequences and Policy Options." Seminar Paper 25-26 January, 2010. Maputo, Mozambique.

[30] Wanjiru, M. E. (2011). Benefits of Market Information Access through Mobile Telephones among Small-scale Farmers: Case Study of NAFIS Application in Kirinyaga County, Kenya.

[31] Martey, E., Alexander, N. W., \& Caleb, A. (2012). Does Access to Market Information Determine the Choice of Marketing Channel among Smallholder Yam Farmers in the Brong Ahafo Region of Ghana? A Multinomial Logit Regression Analysis. Journal of Economics and Sustainable Development ISSN 2222-1700 (Paper) Vol 3, No. 12, 2012.

[32] Jenny, C. Aker. (2008). The Impact of Cell Phones on Grain Markets in Niger. Job Market Paper January, 15, 2008.

[33] Hatzenbuehler, P. L., Abbott, P. C., Abdoulaye, T. (2017). Price transmission in Nigerian food security crop markets. $J$. Agric. Econ. 68 (1), 143-163.

[34] Guillaume Pierre and Jonathan Kaminski. (2018). Cross Country Maize Market Linkages in Africa: Integration and Price Transmission across Local and Global Markets. Rome, Italy. 